\title{
Low-dose $\gamma$-irradiation induces dual radio-adaptive responses depending on the post-irradiation time by altering microRNA expression profiles in normal human dermal fibroblasts
}

\author{
SEUNGHEE BAE ${ }^{1}$, KARAM KIM ${ }^{1}$, HWA JUN CHA ${ }^{1}$, YEONGMIN CHOI ${ }^{1}$, SHANG HUN SHIN $^{1}$, IN-SOOK AN $^{1}$, \\ JAE HO LEE ${ }^{2}$, SU JAE LEE ${ }^{3}$, JI YOUNG KIM ${ }^{4}$, SEON YOUNG NAM ${ }^{4}$ and SUNGKWAN AN ${ }^{1}$ \\ ${ }^{1}$ Molecular-Targeted Drug Research Center and Korea Institute for Skin and Clinical Sciences, Konkuk University, \\ Seoul 143-701; ${ }^{2}$ Laboratory of Molecular Oncology, Cheil General Hospital and Women's Healthcare Center, \\ Kwandong University, College of Medicine, Seoul 100-380; ${ }^{3}$ Department of Chemistry, Hanyang University, \\ Seoul 133-791; ${ }^{4}$ Radiation Effect Research Team, Radiation Health Research Institute, \\ Korea Hydro and Nuclear Power Co., Ltd., Seoul 132-703, Republic of Korea
}

Received April 18, 2014; Accepted October 27, 2014

DOI: $10.3892 /$ ijmm.2014.1994

\begin{abstract}
Exposure to high-dose ionizing radiation, including $\gamma$-radiation, induces severe skin disorders. However, the biological consequences and molecular mechanisms responsible for the response of human skin to low-dose $\gamma$-radiation (LDR) are largely unknown. In the present study, we demonstrate that LDR $(0.1 \mathrm{~Gy})$ induces distinct cellular responses in normal human dermal fibroblasts (NHDFs) depending on the postirradiation time point. A MTT-based cell viability assay and propidium iodide staining-based cell cycle assay revealed that the viability and proportion of the cells in the G2/M phase were differed at 6 and 24 h post-irradiation. Reverse transcription quantitative PCR (RT-qPCR) revealed that LDR significantly upregulated the mRNA expression of collagen type I alpha 1 (COL1A1), but downregulated the mRNA expression of matrix metalloproteinase $1(M M P 1)$ at $24 \mathrm{~h}$ postirradiation. MicroRNA (miRNA) microarray analysis further demonstrated that LDR induced changes in the expression profiles of specific miRNAs and that some of the deregulated miRNAs were specific to either the early or late radio-adaptive response. Our results suggest that LDR generates dual radioadaptive responses depending on the post-irradiation time by altering specific miRNA expression profiles in NHDFs.
\end{abstract}

\section{Introduction}

Since the discovery of radiation, practically every industry has adopted its use in various ways. Consequently, there has been

Correspondence to: Dr Sungkwan An, Molecular-Targeted Drug Research Center and Korea Institute for Skin and Clinical Sciences, Konkuk University, 120 Neungdong-ro, Gwangjin-gu, Seoul 143-701, Republic of Korea

E-mail: ansfgrc@konkuk.ac.kr

Key words: low-dose radiation, microRNA, dermal fibroblasts, expression, radio-adaptive response growing concern about the biological consequences of exposure to low-dose radiation (LDR) from medical processes or other industrial facilities and an increased interest in genes that are specific diagnostic markers of LDR-induced damage (1). However, the exact health risks from exposure to LDR remain controversial and unclear (1). There are currently three models for measuring the effects of LDR on humans. First is the linear non-threshold (LNT) model, which is more commonly applied to high-dose exposure, but suggests that even LDR can increase the risk of carcinogenesis (2). Second, unlike the LNT model, the threshold model suggests that there is a level of radiation exposure that is harmless (3). Third is an alternative model, termed hormesis or adaptive response, which suggests that LDR is potentially protective and has beneficial effects (3).

Skin, which is both the largest organ and the outermost layer of the human body, consists of two main layers, the epidermis and dermis. Human dermal fibroblasts (HDFs) are the most abundant cells in the dermis of the skin, and contribute to skin firmness and elasticity through the synthesis of collagen $(4,5)$. Among the types of collagen, type 1 collagen is the most common type, and is composed of two $\alpha 1(\mathrm{I})$ chains and one $\alpha 2$ (I) chain encoded by the COL1A1 and COL1A2 genes, respectively (5). HDFs also express matrix metalloproteinases (MMPs), which negatively regulate collagen levels through collagen degradation (6). The overexpression of the MMPl gene has been observed in aged/photoaged skin in vivo (6). Reflecting their position in the human body, HDFs are more vulnerable than other cells to toxic environmental agents, such as ultraviolet (UV) radiation and even ionizing radiation. $\mathrm{UV}$-induced photoaging involves the downregulation of COL1A1 and COL1A2 and the consequent loss of collagen, leading to fine wrinkles (4). Moreover, various studies have indicated that skin aging induced by exposure to UV radiation is mediated by the upregulation of MMP1 expression (4). By contrast, $\beta$-radiation has a wound healing effect by increasing the production of collagen I production in skin fibroblasts (7). Although the effects of UV radiation and the underlying mechanisms responsible for UV-mediated cellular responses 
have been extensively studied $(4,8)$, much remains unknown about the biological response of human skin to LDR.

MicroRNAs (miRNAs or miRs) are small RNAs consisting of 19-25 nucleotides that play essential roles in growth, differentiation and cell death (13). A number of studies have demonstrated that miRNAs are important regulators of cellular responses to radiation. For example, miR-34, which is regulated by the p53 tumor suppressor protein (9), is induced by $\gamma$-radiation in vitro and in vivo $(10,11)$. In addition, a recent study demonstrated that the irradiation of human keratinocytes located in the skin epidermis with $10 \mathrm{mGy}$ and 6 Gy of $\gamma$-radiation induces a pattern of miRNA expression that is strongly related to the differentiation status of the irradiated cells (12). Furthermore, our previous study demonstrated that specific miRNAs are expressed in a $\gamma$-radiation dose-dependent manner in the human lymphoblast cell line, IM9 (13). We also identified miR-16, miR-202, miR-303 and miR-572 as ionizing radiation-responsive miRNAs in the IM9 cell line (14). These findings strongly suggest that the elucidation of miRNA-based cellular mechanisms is essential for the understanding of LDR-mediated responses in human skin, and that certain miRNAs may be principal diagnostic markers for LDR responses.

In the present study, we used miRNA microarray analysis to demonstrate that LDR alters the expression profiles of specific miRNAs in normal human dermal fibroblasts (NHDFs). We also demonstrated that the miRNA expression profiles differ at 6 and 24 h post-irradiation. Furthermore, our results indicate that LDR has a potential anti-aging effect through the regulation of COL1A1 and MMP1 expression.

\section{Materials and methods}

Cell culture and irradiation. NHDFs were purchased from Lonza (Basel, Switzerland) and maintained in Dulbecco's modified Eagle's medium (DMEM; Gibco; Life Technologies, Grand Island, NY, USA) containing 10\% fetal bovine serum (FBS; Sigma-Aldrich, St. Louis, MO, USA). To evaluate the pattern of the cell cycle and miRNA expression, $7 \times 10^{5}$ cells were seeded onto $60-\mathrm{mm}$ culture plates and cultured for $24 \mathrm{~h}$. The cells were irradiated with $0.1 \mathrm{~Gy}$ of $\gamma$-radiation using a Gammacell 3000 Elan irradiator $\left({ }^{137} \mathrm{Cs} \gamma\right.$-ray source; MDS Nordion, Ottawa, ON, Canada).

Cell viability assay. The cytotoxic effects of $\gamma$-radiation $(0.1 \mathrm{~Gy})$ on the NHDFs were investigated using a 3-(4,5-dimethylthiazol-2-yl)-2,5-diphenyltetrazolium bromide (MTT) assay (Sigma-Aldrich) according to the manufacturer's instructions. Briefly, the NHDFs were seeded and irradiated with $0.1 \mathrm{~Gy}$ of $\gamma$-radiation. Following incubation for 6 or $24 \mathrm{~h}$, MTT solution was added to the cultured cells, followed by incubation at $37^{\circ} \mathrm{C}$ for $1 \mathrm{~h}$. The medium was removed and the blue formazan crystals trapped in the cells were dissolved in dimethyl sulfoxide (DMSO) (Sigma-Aldrich). Cell viability was measured using an iMark plate reader (Bio-Rad, Hercules, CA, USA) at $590 \mathrm{~nm}$ with a reference filter of $620 \mathrm{~nm}$. All results are presented as the mean percentage \pm standard deviation (SD) of 3 independent experiments. A P-value $<0.05$ as determined by the Student's t-test was considered to indicate a statistically significant difference.
Analysis of cell cycle by flow cytometry. To analyze the cells in different phases of the cell cycle, irradiated NHDFs were fixed by the addition of cold $70 \%$ ethanol and stained by incubation with propidium iodide (PI) staining solution [50 $\mu \mathrm{g} / \mathrm{ml} \mathrm{PI}$, $0.5 \%$ Triton X-100 (both from Sigma-Aldrich), and $100 \mu \mathrm{g} / \mathrm{ml}$ RNase (Qiagen, Hilden, Germany)] at $37^{\circ} \mathrm{C}$ for $1 \mathrm{~h}$. The PI fluorescence intensity was detected using a BD FACSCalibur flow cytometer (BD Biosciences, San Jose, CA, USA). The mean PI fluorescence intensity was obtained from 10,000 cells using the FLH-2 channel.

RNA purification and reverse transcription-quantitative polymerase chain reaction $(R T-q P C R)$. Total RNA was purified using TRIzol reagent (Life Technologies, Carlsbad, CA, USA) according to the manufacturer's instructions. The purity and concentration of the RNA was assessed by the ratio of absorbance at 230, 260 and $280 \mathrm{~nm}$ using MaestroNano ${ }^{\circledR}$, a micro-volume spectrophotometer (Maestrogen, Las Vegas, NV, USA). cDNA was synthesized using a SuperScript ${ }^{\circledR}$ III First-Strand Synthesis system for RT-PCR (Life Technologies). Quantitative (real-time) PCR was performed using SYBR ${ }^{\circledR}$ Green PCR Master Mix and SYBR ${ }^{\circledR}$-Green RT-PCR reagents kit (Life Technologies) with specific primers for COL1A1 and $M M P 1$ and a Line-Gene K RT-PCR instrument (Bioer Technology Co., Ltd., Hangzhou, China). The CT value for each gene was normalized to glyceraldehyde 3-phosphate dehydrogenase $(G A P D H)$. The $2^{-\triangle \Delta \mathrm{CT}}$ method was used to calculate the relative expression level of each gene. The forward (F) and reverse (R) primers for human COLIAl, $M M P 1$ and $G A P D H$ were 5'-AGCCAGCAGATCGAG AACAT-3' (COL1Al-F) and 5'-TCTTGTCCTTGGGGTT CTTG-3' (COL1A1-R); 5'-GATGTGGAGTGCCTGATGTG-3' $(M M P l-F)$ and 5'-TGCTTGACCCTCAGAGACCT-3' $(M M P 1-R) ;$ 5'-CGCTCTCTGCTCCTCCTGTT-3' (GAPDH-F) and 5'-CCATGGTGTCTGAGCGATGT-3' (GAPDH-R).

miRNA microarray analysis. RNA integrity was estimated using an Agilent 2100 Bioanalyzer ${ }^{\circledR}$ (Agilent Technologies, Santa Clara, CA, USA). RNA samples that showed A260/280 and A260/A230 values $>1.8$ and an RNA integrity number $>8.0$ were subjected to microRNA-based microarray analysis. Microarray analysis was performed using a SurePrint G3 Human version 16 miRNA 8x60K microarray kit (Agilent Technologies), according to a previously described protocol (15). Briefly, 50 ng of purified RNA were treated with calf intestine alkaline phosphatase and labeled with cyanine 3-cytidine bisphosphate. The labeled RNA was purified using a Micro Bio-Spin P-6 column (Bio-Rad Laboratories, Hercules, CA, USA) and hybridized with the microarray kit. The fluorescence intensity of each probe was measured using Scanner and Feature Extraction software (Agilent Technologies). The digitalized fluorescence intensity was analyzed using GeneSpring GX version 11.5 software (Agilent Technologies). The raw data were filtered using FLAG and t-tests, and applied to the fold change analysis. The fold change analysis was conducted based on a factor of 2.0-fold change between nonirradiated control cells and irradiated cells.

Target prediction and bioinformatics analysis of miRNAs. We first analyzed putative target genes of the miRNAs using the 

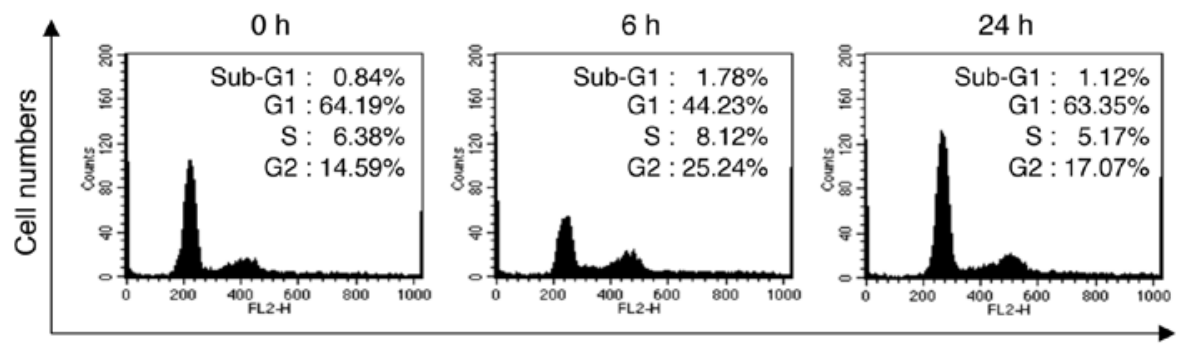

PI intensity

Figure 1. Low-dose $\gamma$-radiation induces G2/M arrest in normal human dermal fibroblasts (NHDFs). Cells were seeded on 60-mm culture dishes and irradiated with low-dose $(0.1 \mathrm{~Gy}) \gamma$-radiation. Following incubation for 6 and $24 \mathrm{~h}$, the cells were fixed with ethanol and stained with propidium iodide (PI) solution. The cell cycle was evaluated by flow cytometry.

A

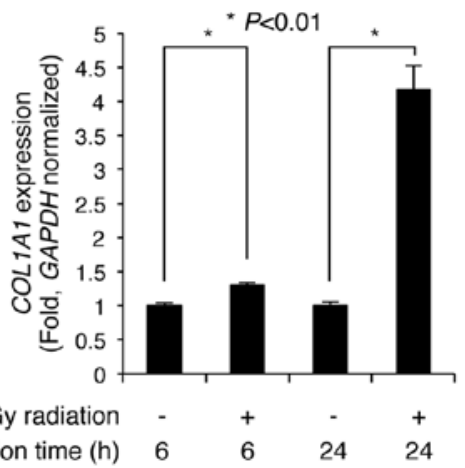

B

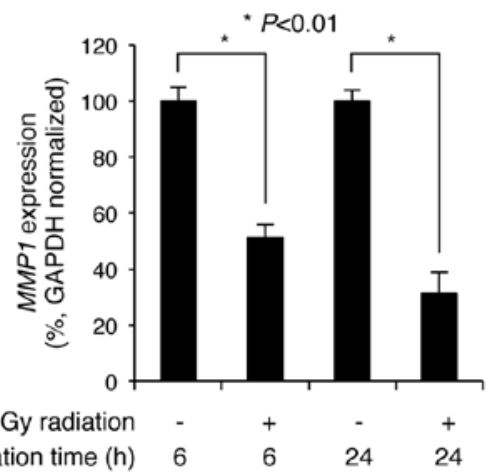

Figure 2. Low-dose $\gamma$-radiation regulates the expression levels of collagen type I alpha 1 (COL1A1) and matrix metalloproteinase 1 (MMP1) in normal human dermal fibroblasts (NHDFs). Cells were exposed to 0.1 Gy $\gamma$-radiation and further incubated for 6 and $24 \mathrm{~h}$. Irradiated cells and control cells were subjected to RT-qPCR to determine the expression of (A) COL1A1 and (B) MMP1. Expression was normalized to that of glyceraldehyde 3-phosphate dehydrogenase $(G A P D H)$. Data shown are representative of 3 independent experiments [means \pm standard deviation $(\mathrm{SD})$ ]. ${ }^{*} \mathrm{P}<0.01$ compared with the controls.

DIANA-microT bioinformatic software tool (http://diana.imis. athena-innovation.gr/DianaTools/index.php?r=microT_CDS/ index), as previously described (16). The prediction of target genes was limited by setting the threshold value to 0.8 . The putative target genes of each miRNA were further analyzed for biological function using the Kyoto Encyclopedia of Genes and Genomes (KEGG) pathways and Database for Annotation, Visualization and Interrogate Discovery (DAVID, http://david. abcc.ncifcrf.gov/home.jsp) bioinformatics resources version 6.7 according to the developer's protocol (17). The 'KEGG_pathway' category was processed by setting the threshold of EASE score, a modified Fisher exact P-value, to 0.1 , and involved KEGG pathways displaying a value $>1 \%$ (percentage of involved target genes/total target genes in each pathway) were selected.

\section{Results}

Cell cycle arrest in the G2/M phase is an early adaptive response to $L D R$ in NHDFs. We first determined whether LDR $(0.1 \mathrm{~Gy})$ affects the viability of NHDFs. For a more precise analysis, the effects of LDR on cell viability were analyzed at 2 different time points (6 and $24 \mathrm{~h}$ ) after irradiation. There were no marked differences in the viability of the cells exposed to LDR and the control cells, as determined by MTT assay. At 6 and $24 \mathrm{~h}$ after irradiation, cell viability was reduced to $92.94 \pm 3.53$ and $98.04 \pm 1.82 \%$ of the control value, respectively (data not shown). We then examined the cell cycle patterns following the exposure of NHDFs to LDR. The cells were irradiated with $0.1 \mathrm{~Gy}$ of $\gamma$-radiation and then incubated for 6 and $24 \mathrm{~h}$. Following incubation, the cells were stained with PI and the cell cycle distribution was analyzed by flow cytometry. Exposure to LDR decreased the proportion of cells in the G1 phase from $64.19 \%$ at $0 \mathrm{~h}$ to $44.23 \%$ at $6 \mathrm{~h}$ post-irradiation, whereas the proportion of cells in the $\mathrm{G} 2 / \mathrm{M}$ phase increased from 14.59 to $25.24 \%$ (Fig. 1). Of note, at $24 \mathrm{~h}$ post-irradiation, the proportion of cells in the $\mathrm{G} 1$ phase was $63.35 \%$ and the proportion of cells in the G2/M phase was $17.07 \%$. These results indicate that $\mathrm{G} 2 / \mathrm{M}$ cell cycle arrest was observed in the NHDFs at a relatively early time point $(\sim 6 \mathrm{~h})$ post-irradiation; however, this arrest was reversed at later time points $(24 \mathrm{~h})$ post-irradiation.

Low-dose radiation alters the expression levels of COL1A1 and MMP1 in NHDFs. NHDFs within the dermis layer of the skin contribute to skin firmness and elasticity by regulating the expression of genes associated with collagen synthesis, including COLIAI and MMPI (5). Therefore, we wished to examined whether LDR affects the expression levels of these genes. The NHDFs were seeded and irradiated with $0.1 \mathrm{~Gy}$ of $\gamma$-radiation. Following irradiation, the cells were incubated for an additional 6 and $24 \mathrm{~h}$, and then subjected to RT-qPCR to determine the expression levels of COL1A1 and MMP1. Compared with the non-irradiated control cells, COL1A1 
A

At $6 \mathrm{~h}$ after irradiation

\begin{tabular}{|c|c|c|}
\hline IR (0.1 Gy) & - & + \\
\hline let-7a-3p & & \\
\hline miR-101-3p & & \\
\hline miR-1181 & & \\
\hline miR-1225-3p & & \\
\hline$m i R-1226-5 p$ & & \\
\hline miR-1228-3p & & \\
\hline miR-1234-3p & & \\
\hline$m i R-1238-3 p$ & & \\
\hline miR-125a-3p & & \\
\hline miR-1268a & & \\
\hline miR-1275 & & \\
\hline miR-128 & & \\
\hline miR-1281 & & \\
\hline miR-1288 & & \\
\hline miR-129-2-3p & & \\
\hline miR-1290 & & \\
\hline miR-130b-3p & & \\
\hline miR-132-3p & & \\
\hline miR-134 & & \\
\hline miR-135a-3p & & \\
\hline miR-136-3p & & \\
\hline miR-138-5p & & \\
\hline miR-138-2-5p & & \\
\hline $\operatorname{miR}-140-3 p$ & & \\
\hline $\operatorname{miR}-140-5 p$ & & \\
\hline$m i R-146 b-5 p$ & & \\
\hline$m i R-148 b-3 p$ & & \\
\hline miR-150-3p & & \\
\hline miR-151-3p & & \\
\hline miR-154-3p & & \\
\hline miR-17-3p & & \\
\hline miR-1825 & & \\
\hline $\operatorname{miR}-185-5 p$ & & \\
\hline$m i R-186-5 p$ & & \\
\hline miR-188-5p & & \\
\hline$m i R-18 a-5 p$ & & \\
\hline miR-18b-5p & & \\
\hline miR-191-3p & & \\
\hline miR-1914-3p & & \\
\hline miR-193a-5p & & \\
\hline miR-1973 & & \\
\hline miR-202-3p & & \\
\hline miR-210 & & \\
\hline $\begin{array}{l}\text { miR-214-5p } \\
\text { miR-23a-5p }\end{array}$ & & \\
\hline
\end{tabular}

(continued)

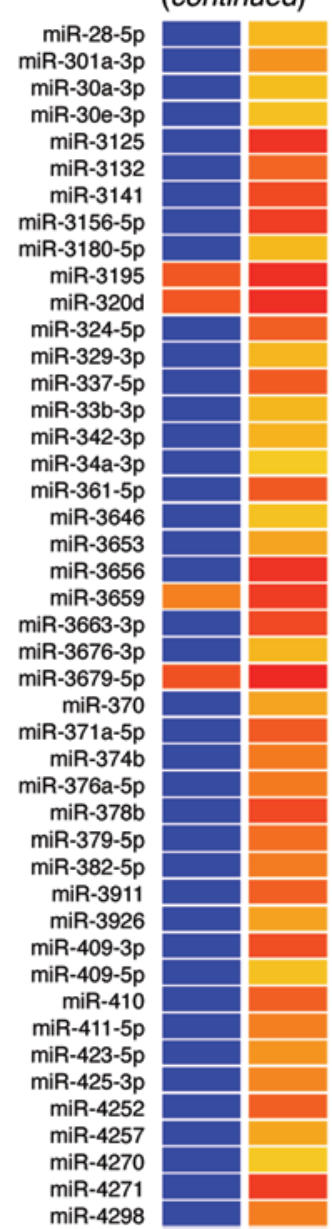

\section{(continued)}

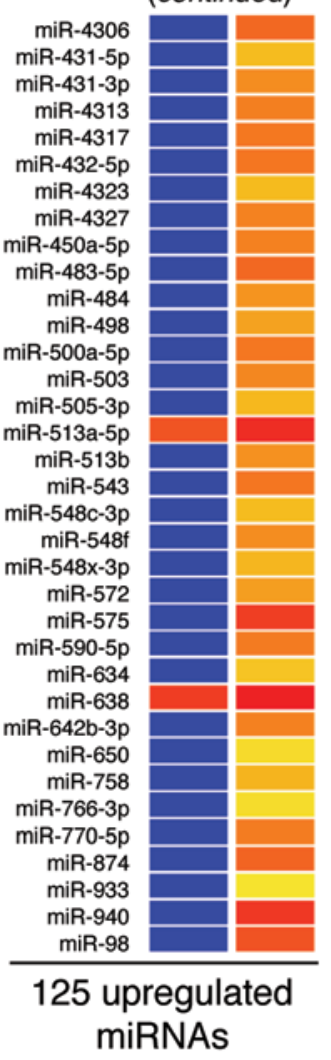

Expression level

$\begin{array}{lll}-4.2 & 0 & 4.2\end{array}$

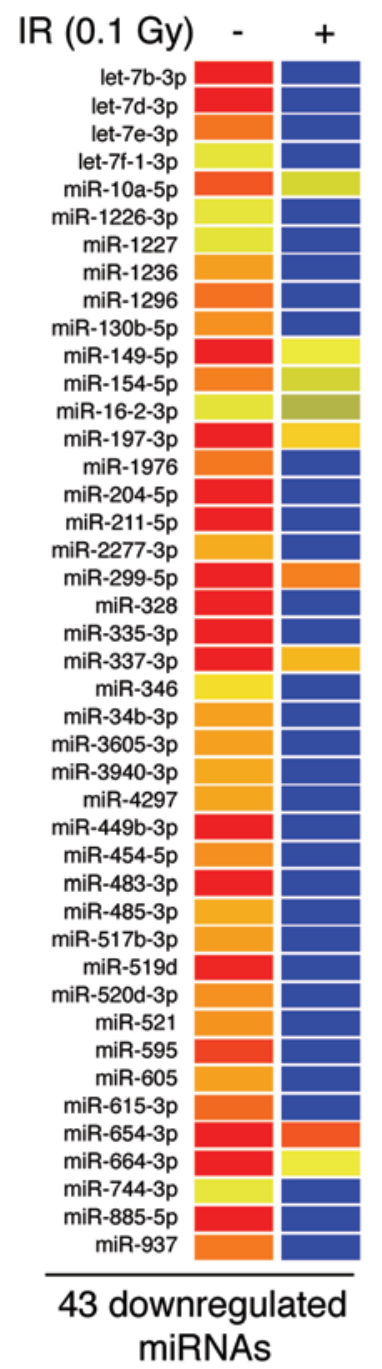

B

At $24 \mathrm{~h}$ after Irradiation

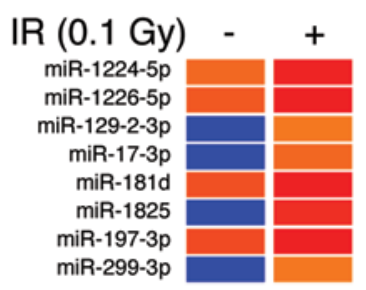

\begin{tabular}{rll}
\multicolumn{3}{c}{ (continued) } \\
miR-3180-5p & & \\
miR-33b-3p & & \\
miR-3646 & & \\
miR-3648 & & \\
miR-369-3p & & \\
miR-369-5p & & \\
miR-3937 & & \\
miR-431-5p & & \\
\hline
\end{tabular}
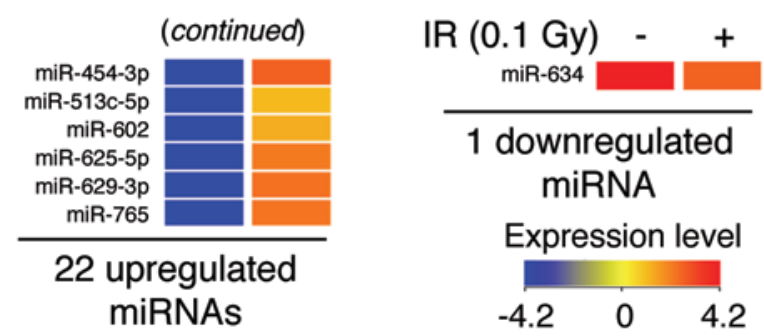

Figure 3. Low-dose $\gamma$-radiation alters the pattern of microRNA (miRNA) expression in normal human dermal fibroblasts (NHDFs). Heatmap representing changes in miRNA expression profiles at (A) $6 \mathrm{~h}$ and (B) $24 \mathrm{~h}$ following the irradiation of NHDFs. Cells were exposed to 0.1 Gy $\gamma$-radiation and then incubated for 6 and $24 \mathrm{~h}$ prior to miRNA microarray analysis. The heatmap shows deregulated miRNAs with 2 -fold change in Cy3 fluorescence (upregulated or downregulated) in irradiated cells compared with the non-irradiated control cells.

expression was slightly increased $1.29 \pm 0.03$-fold $(n=3)$ at $6 h$ post-irradiation, but markedly increased $4.17 \pm 0.34$-fold $(n=3)$ by $24 \mathrm{~h}$ post-irradiation (Fig. 2A). Additionally, $M M P 1$ expression significantly decreased to $51.37 \pm 4.49$ and $31.33 \pm 7.44 \%$ $(n=3)$ of the control levels at 6 and $24 \mathrm{~h}$ following irradiation, respectively (Fig. 2B). These results indicate that LDR significantly induces the upregulation of COLIAI and the downregulation of $M M P 1$ in NHDFs.
Specific miRNAs respond to LDR in NHDFs. Although it is known that miRNA-mediated processes are important in the cellular response to radiation (18), to the best of our knowledge, miRNA responses to LDR ( $\geq 0.1 \mathrm{~Gy}$ ) in NHDFs have not previously been investigated. To explore the role of miRNAs in LDR-mediated cellular responses in NHDFs, we performed miRNA microarray analysis using a SurePrint G3 Human version 16 miRNA 8x60K microarray, which contains 
A

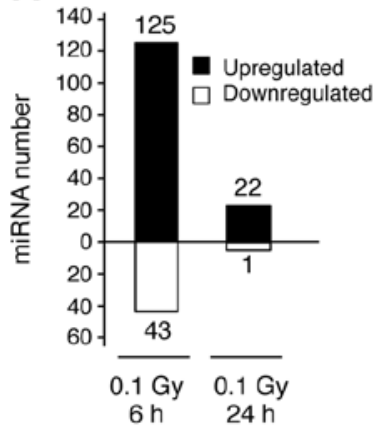

B

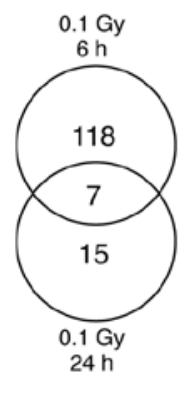

C

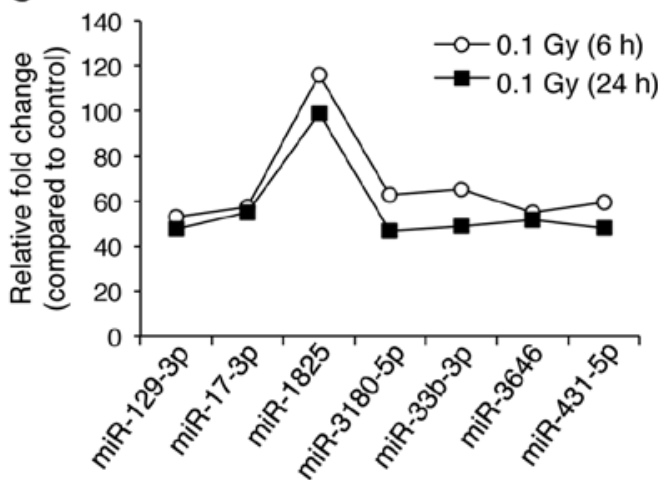

Figure 4. Low-dose $\gamma$-radiation induces differential microRNA (miRNA) expression depending on the duration of incubation following irradiation. (A) Graph showing the number of deregulated miRNAs in normal human dermal fibroblasts (NHDFs) at 6 and $24 \mathrm{~h}$ after irradiation compared with the non-irradiated control cells. (B) Venn diagram showing the number of upregulated (>2-fold change in expression) miRNAs. In total, 7 miRNAs showed an altered expression at both the 6 and $24 \mathrm{~h}$ time points after irradiation in the NHDFs. (C) Graph showing the fold change in expression of these 7 miRNAs in NHDs at different time points after irradiation.

2,006 human miRNA probes. Purified RNA isolated from the cells at 6 and $24 \mathrm{~h}$ post-irradiation was labeled and hybridized onto the microarray as described in the 'Materials and methods'. miRNAs that showed a $\geq 2$.0-fold increase or decrease in expression were selected using GeneSpring GX software. A number of miRNAs were found to be significantly regulated in response to LDR in the NHDFs (Fig. 3). At $6 \mathrm{~h}$ post-irradiation, 125 miRNAs were upregulated and 43 miRNAs were downregulated, indicating that LDR induces changes in the expression of specific miRNAs during the early adaptive response in NHDFs (Figs. 3A and 4A). Notably, the expression levels of miR-3656, miR-3125 and miR-940 were significantly increased by 493.88-, 493.78- and 450.69-fold, respectively, whereas the expression levels of miR-328, miR-885-5p and let-7d-3p were significantly downregulated by 967.50-, 934.72- and 822.64-fold, respectively (Table I). Additionally, 22 miRNAs were upregulated and 1 miRNA was downregulated at $24 \mathrm{~h}$ post-irradiation (Figs. 3B and 4A). Of these, miR-3937, miR-1825 and miR-369-3p were significantly upregulated by $121.42-$, 98.92- and 63.70-fold, whereas the expression level of miR-634 was downregulated by 2.32-fold (Table II). The complete list of differentially expressed miRNAs is provided in Tables I and II. These data suggest that miRNA-mediated responses are essential in the cellular radio-adaptive response to LDR in NHDFs.

Bioinformatics analysis of differentially expressed miRNAs in response to $L D R$. We then analyzed the biological characteristics of the miRNAs that were upregulated in response to LDR at 6 and $24 \mathrm{~h}$ (125 'early' and 22 'late' miRNAs) (Fig. 4A). Of the 125 miRNAs, 117 were specifically upregulated in the early response group only $(6 \mathrm{~h}$ after irradiation), whereas 15 of the 22 miRNAs were specifically upregulated in the late response group only ( $24 \mathrm{~h}$ after irradiation), respectively (Fig. 4B). Of note, 7 miRNAs (miR-129-3p, miR-17-3p, miR-1825, miR-3180-5p, miR-33b-3p, miR-3646 and miR-431-5p) were upregulated in both groups (6 and $24 \mathrm{~h}$ post-irradiation) (Fig. 4C). Furthermore, the expression levels of these 7 miRNAs showed only minor differences between the late and early response groups (Fig. 4C), indicating that these are miRNAs whose expression is generally altered in response to LDR in NHDFs.

Since miRNAs are essential regulators of almost all cellular functions, including cell proliferation, senescence and apoptosis through the modulation of target mRNA translation (19), we investigated the biological relevance of miRNA dysregulation in the LDR-induced radio-adaptive response in NHDFs. First, we identified the predicted target genes of each miRNA that was significantly regulated in response to LDR in this study using the DIANA-microT-CDS (version 5.0) webbased software tool with a threshold value of 0.8 . Following target prediction, we collected information on the Ensembl transcript ID of the targets and performed KEGG pathway analysis for the targets using DAVID bioinformatics resources. To improve accuracy, the Ease Score, which is a modified Fisher extract P-value, was fixed at 0.1 and meaningful KEGG pathways showing a value $>1 \%$ (percentage of involved target genes/total genes involved in each pathway) were selected. Table III shows specific pathways for the targets of upregulated miRNAs in the early response group ( $6 \mathrm{~h}$ post-irradiation) and the specific pathways for the targets of the downregulated miRNAs in the early response group are presented in Table IV. Of these, the targets of miR-940, which was highly upregulated (450.69-fold) in the early response group, are functionally involved in the following cancer-related pathways: mitogenactivated protein kinase (MAPK), WNT, Janus kinase/signal transducers and activators of transcription (Jak-STAT), transforming growth factor- $\beta$ (TGF- $\beta$ ) and ErbB signaling. The targets of miR-328, which was the most highly downregulated miRNA in the early response group, are involved in the p53 and mammalian target of rapamycin (mTOR) signaling pathways. Specific pathways for the targets of upregulated and downregulated miRNAs in the late response group to LDR are shown in Table V. The complete information of the KEGG pathways for the miRNAs is provided in Tables III-V.

\section{Discussion}

The present study demonstrates that LDR (0.1 Gy) induces distinct cellular responses in NHDFs. A MTT-based cell 
Table I. miRNAs that showed a $>2$-fold change in expression in NHDFs at $6 \mathrm{~h}$ following exposure to $0.1 \mathrm{~Gy} \gamma$-radiation.

\begin{tabular}{|c|c|c|c|c|c|c|c|}
\hline $\begin{array}{l}\text { miRNA } \\
\text { (Homo sapiens) }\end{array}$ & Fold change & miRNA & Fold change & miRNA & Fold change & miRNA & Fold change \\
\hline let-7a-3p & 42.0 & $\operatorname{miR}-210$ & 53.1 & miR-425-3p & 130.6 & let-7d-3p & -822.6 \\
\hline miR-101-3p & 193.4 & miR-214-5p & 67.0 & miR-4252 & 234.1 & let-7e-3p & -289.5 \\
\hline miR-1181 & 319.3 & miR-23a-5p & 28.0 & miR-4257 & 82.0 & let- $7 f-1-3 p$ & -116.1 \\
\hline miR-1225-3p & 139.0 & $\operatorname{miR}-28-5 p$ & 64.3 & miR-4270 & 50.3 & miR-10a-5p & -4.3 \\
\hline miR-1226-5p & 136.2 & miR-301a-3p & 107.8 & miR-4271 & 405.0 & miR-1226-3p & -119.5 \\
\hline miR-1228-3p & 259.7 & miR-30a-3p & 58.9 & miR-4298 & 145.9 & miR-1227 & -114.8 \\
\hline miR-1234-3p & 261.6 & $\operatorname{miR}-30 e-3 p$ & 56.5 & miR-4306 & 203.6 & miR-1236 & -235.3 \\
\hline miR-1238-3p & 193.0 & miR-3125 & 493.8 & miR-431-5p & 59.5 & miR-1296 & -292.4 \\
\hline$m i R-125 a-3 p$ & 195.2 & miR-3132 & 215.1 & miR-431-3p & 118.4 & miR-130b-5p & -251.2 \\
\hline miR-1268a & 320.7 & miR-3141 & 331.3 & miR-4313 & 144.6 & miR-149-5p & -3.6 \\
\hline miR-1275 & 236.8 & miR-3156-5p & 404.0 & miR-4317 & 160.7 & miR-154-5p & -3.6 \\
\hline miR-128 & 76.4 & miR-3180-5p & 62.5 & miR-432-5p & 165.2 & miR-16-2-3p & -2.9 \\
\hline miR-1281 & 153.5 & miR-3195 & 2.1 & $\operatorname{miR}-4323$ & 61.0 & miR-197-3p & -5.3 \\
\hline miR-1288 & 248.4 & miR-320d & 2.0 & miR-4327 & 139.7 & miR-1976 & -282.3 \\
\hline miR-129-2-3p & 52.7 & miR-324-5p & 229.7 & miR-450a-5p & 140.4 & miR-204-5p & -690.8 \\
\hline miR-1290 & 135.6 & miR-329-3p & 65.6 & miR-483-5p & 202.3 & miR-211-5p & -695.8 \\
\hline miR-130b-3p & 285.6 & $\operatorname{miR}-337-5 p$ & 249.5 & miR-484 & 105.4 & miR-2277-3p & -222.3 \\
\hline miR-132-3p & 214.9 & miR-33b-3p & 65.0 & miR-498 & 86.3 & miR-299-5p & -2.7 \\
\hline miR-134 & 215.9 & miR-342-3p & 68.9 & miR-500a-5p & 162.6 & miR-328 & -967.5 \\
\hline miR-135a-3p & 64.0 & miR-34a-3p & 49.1 & miR-503 & 127.6 & miR-335-3p & -487.7 \\
\hline miR-136-3p & 121.1 & $\operatorname{miR}-361-5 p$ & 256.2 & miR-505-3p & 64.2 & miR-337-3p & -4.6 \\
\hline miR-138-5p & 223.7 & miR-3646 & 55.1 & miR-513a-5p & 2.0 & miR-346 & -176.7 \\
\hline miR-138-2-5p & 109.3 & miR-3653 & 84.3 & miR-513b & 111.6 & miR-34b-3p & -234.2 \\
\hline miR-140-3p & 84.9 & miR-3656 & 493.9 & miR-543 & 166.3 & miR-3605-3p & -234.6 \\
\hline miR-140-5p & 186.7 & miR-3659 & 2.8 & $\operatorname{miR}-548 c-3 p$ & 59.9 & miR-3940-3p & -225.0 \\
\hline miR-146b-5p & 52.4 & miR-3663-3p & 337.7 & miR-548f & 117.5 & miR-4297 & -227.1 \\
\hline miR-148b-3p & 233.3 & $\operatorname{miR}-3676-3 p$ & 65.3 & $\operatorname{miR}-548 x-3 p$ & 66.2 & miR-449b-3p & -652.7 \\
\hline miR-150-3p & 333.3 & miR-3679-5p & 2.2 & miR-572 & 92.5 & miR-454-5p & -253.7 \\
\hline miR-151-3p & 277.5 & miR-370 & 84.7 & miR-575 & 401.3 & miR-483-3p & -746.1 \\
\hline miR-154-3p & 180.8 & miR-371a-5p & 251.2 & miR-590-5p & 153.7 & miR-485-3p & -223.1 \\
\hline miR-17-3p & 57.4 & miR-374b & 156.3 & miR-634 & 53.6 & $\operatorname{miR}-517 b-3 p$ & -236.8 \\
\hline miR-1825 & 115.9 & miR-376a-5p & 156.1 & miR-638 & 2.0 & miR-519d & -447.1 \\
\hline miR-185-5p & 136.3 & miR-378b & 336.1 & $\operatorname{miR}-642 b-3 p$ & 141.5 & $\operatorname{miR}-520 d-3 p$ & -251.4 \\
\hline miR-186-5p & 181.3 & miR-379-5p & 186.6 & $\mathrm{miR}-650$ & 38.7 & $\operatorname{miR}-521$ & -248.1 \\
\hline miR-188-5p & 120.5 & miR-382-5p & 153.4 & miR-758 & 67.6 & miR-595 & -366.8 \\
\hline miR-18a-5p & 160.3 & miR-3911 & 229.8 & miR-766-3p & 37.7 & miR-605 & -233.4 \\
\hline miR-18b-5p & 44.7 & miR-3926 & 86.6 & miR-770-5p & 150.2 & miR-615-3p & -302.1 \\
\hline miR-191-3p & 175.7 & miR-409-3p & 310.1 & miR-874 & 217.3 & miR-654-3p & -2.4 \\
\hline miR-1914-3p & 2.0 & miR-409-5p & 56.5 & miR-933 & 34.0 & miR-664-3p & -3.7 \\
\hline miR-193a-5p & 265.3 & miR-410 & 234.0 & miR-940 & 450.7 & miR-744-3p & -122.9 \\
\hline miR-1973 & 285.5 & miR-411-5p & 145.1 & miR-98 & 286.4 & miR-885-5p & -934.7 \\
\hline miR-202-3p & 154.2 & miR-423-5p & 106.4 & let-7b-3p & -510.3 & miR-937 & -282.1 \\
\hline
\end{tabular}

miRNAs, microRNAs; NHDFs, normal human dermal fibroblasts.

viability assay demonstrated a slight decrease in cell viability at $6 \mathrm{~h}$ after irradiation, but this decrease was reversed by $24 \mathrm{~h}$ after irradiation. Similar results were obtained by FACS analysis and PI staining; at $6 \mathrm{~h}$ after irradiation the proportion of irradiated cells which had accumulated in the G2/M phase was markedly higher than that of non-irradiated cells; however, this value had returned close to the value of the control at $24 \mathrm{~h}$. These data indicate that NHDFs have distinct radio-adaptive 
Table II. miRNAs that showed a $>2$-fold change in expression in NHDFs at $24 \mathrm{~h}$ following exposure to $0.1 \mathrm{~Gy} \gamma$-radiation.

\begin{tabular}{lclcrccc}
\hline $\begin{array}{l}\text { miRNA } \\
\text { (Homo sapiens) }\end{array}$ & Fold change & miRNA & Fold change & miRNA & Fold change & miRNA & Fold change \\
\hline miR-1224-5p & 2.2 & miR-197-3p & 2.2 & miR-369-3p & 63.7 & miR-602 \\
miR-1226-5p & 2.0 & miR-299-3p & 48.3 & miR-369-5p & 55.1 & miR-625-5p & 46.9 \\
miR-129-2-3p & 47.7 & miR-3180-5p & 46.7 & miR-3937 & 121.4 & miR-629-3p & 50.4 \\
miR-17-3p & 55.1 & miR-33b-3p & 49.0 & miR-431-5p & 48.0 & miR-765 & 49.3 \\
miR-181d & 2.1 & miR-3646 & 51.6 & miR-454-3p & 58.1 & miR-634 \\
miR-1825 & 98.9 & miR-3648 & 47.7 & miR-513c-5p & 27.1 & \\
\hline
\end{tabular}

miRNAs, microRNAs; NHDFs, normal human dermal fibroblasts.

responses to LDR at different time points post-irradiation. The early radio-adaptive response to LDR appears to activate cell cycle arrest mechanisms, but does not fully block cell cycle progression. By contrast, the late radio-adaptive response to LDR may activate radioresistance mechanisms. A slight decrease in cell viability and a partial increase in the G2/M cell population were only evident at $6 \mathrm{~h}$ post-irradiation; by $24 \mathrm{~h}$ post-irradiation, the decrease in cell viability and G2/M cell cycle arrest were reversed and had returned close to the control levels. A similar result was reported in a previous study on human glioblastoma T98G and U373MG cell lines, in which the percentage of cells in the $\mathrm{G} 2 / \mathrm{M}$ phase of the cell cycle following exposure to different doses of $\gamma$-radiation (0.2-2 Gy) increased as early as $8 \mathrm{~h}$ following exposure to radiation, although this accumulation was clearly transient and its duration was proportional to the exposure dose (20). In addition, in our previous study, we demonstrated similar results in the human B lymphoblastic cell line, IM9, which showed a marked increase in the proportion of cells in the G2/M phase within $6 \mathrm{~h}$ after exposure to $1 \mathrm{~Gy}$ of $\gamma$-radiation (14). Collectively, our data indicate that the radio-adaptive response of human skin fibroblasts to 0.1 Gy of $\gamma$-radiation involves dual mechanisms depending on the time point following exposure.

We also found that exposure to $0.1 \mathrm{~Gy}$ of $\gamma$-radiation had a potential anti-aging effect on NHDFs. At $24 \mathrm{~h}$ after exposure to LDR, there was a marked increase in the expression of $C O L 1 A 1$ and a decrease in the expression of $M M P 1$. However, the anti-aging effects of LDR must be considered in relation to its safety as the overproduction of collagen is one of the etiological factors of the skin disease, scleroderma (21). A similar result was previously reported using single doses of $\beta$-radiation in human Tenon's capsule fibroblasts (hTfs) (7). A growth-arresting dose (1,000 cGy) of $\beta$-radiation increases the production of collagen $I$ and therefore has a wound healing effect (7). However, various aspects of this response, including collagen structure and skin inflammation following exposure to LDR, have not yet been investigated, and further in vitro and in vivo experiments are required to fully clarify this issue.

In the present study, data from a MTT-based cell viability assay and a FACS-based cell cycle analysis assay revealed that the early radio-adaptive response of NHDFs involving a decrease in cell viability and $\mathrm{G} 2 / \mathrm{M}$ phase arrest was reversed to near-control levels by $24 \mathrm{~h}$ post-irradiation. Although these results suggest that cellular conditions at $24 \mathrm{~h}$ after irradiation are similar to those of control (non-irradiated) cells, our additional data clearly indicate that these cell conditions differ from each other. Firstly, RT-qPCR demonstrated that the intracellular levels of COLIA 1 and $M M P 1$ transcripts were markedly altered $24 \mathrm{~h}$ following exposure to $0.1 \mathrm{~Gy}$ of $\gamma$-radiation. Secondly, miRNA microarray analysis revealed that microRNA expression patterns differed significantly between the control cells and the irradiated cells at $24 \mathrm{~h}$ post-irradiation. Thirdly, the expression levels of the altered miRNAs were markedly different in the irradiated cells from those in the control cells. Notably, the expression levels of 16 miRNAs, including miR-3937 and miR-1825, were significantly increased by $>40$-fold at $24 \mathrm{~h}$ post-irradiation. These results indicated that, although cell viability and cell cycle distribution were reversed, returning to values close to the control values, the intercellular conditions at $24 \mathrm{~h}$ post-irradiation differed from those of the non-irradiated control cells and the irradiated cells presumably had distinct cellular properties.

Using miRNA microarray analysis, we revealed the existence of specific miRNAs in NHDFs with early and late radio-adaptive responses following exposure to $0.1 \mathrm{~Gy}$ $\gamma$-radiation. Among the early response miRNAs, the biological functions of miR-3656 and miR-3125, which were the most highly upregulated (493.88- and 493.78-fold, respectively), to the best of our knowledge, have not been previously studied. Our bioinformatics analysis revealed that these two miRNAs are functionally related to the Wnt signaling pathway. A recent study demonstrated that LDR $(0.3 \mathrm{~Gy})$ stimulates Wnt/ $\beta$-catenin signaling to induce neural stem cell proliferation (22). Therefore, these 2 miRNAs may be valuable novel targets for radio-adaptive response mechanisms. In addition, among the miRNAs that showed an altered expression in the present study, 7 miRNAs (miR-129-3p, miR-17-3p, miR-1825, miR-3180-5p, miR-33b-3p, miR-3646 and miR-431-5p) were upregulated at both 6 and $24 \mathrm{~h}$ following exposure to LDR and are potential LDR-specific biomarkers in human skin. Moreover, the expression levels of these miRNAs were highly upregulated by $>40$-fold and were consistent between the 2 post-irradiation time points. These data indicate that these miRNAs are constantly expressed following exposure to LDR, independent of the post-irradiation time point. 
Table III. Functional annotation chart for the top 20 miRNAs that were upregulated in the NHDFs $6 \mathrm{~h}$ following exposure to 0.1 Gy $\gamma$-radiation.

\begin{tabular}{|c|c|c|c|c|c|}
\hline $\begin{array}{l}\text { miRNA } \\
\text { (Homo sapiens) }\end{array}$ & $\begin{array}{l}\text { Putative } \\
\text { target genes }\end{array}$ & KEGG pathway & $\begin{array}{l}\text { Genes involved } \\
\text { in the term }\end{array}$ & $\begin{array}{c}\% \text { of involved } \\
\text { genes/total genes }\end{array}$ & P-value \\
\hline miR-1181 & - & - & - & - & - \\
\hline miR-1228-3p & 198 & - & - & - & - \\
\hline miR-1234-3p & 19 & - & - & - & - \\
\hline miR-1268a & 6 & - & - & - & - \\
\hline \multirow[t]{6}{*}{ miR-130b-3p } & 473 & Endocytosis & 12 & 2.5 & $8.80 \mathrm{E}-03$ \\
\hline & & TGF- $\beta$ signaling pathway & 9 & 1.9 & $1.90 \mathrm{E}-03$ \\
\hline & & Insulin signaling pathway & 9 & 1.9 & $2.50 \mathrm{E}-02$ \\
\hline & & Phosphatidylinositol signaling system & 8 & 1.7 & $3.10 \mathrm{E}-03$ \\
\hline & & ErbB signaling pathway & 6 & 1.3 & $7.90 \mathrm{E}-02$ \\
\hline & & mTOR signaling pathway & 5 & 1.1 & $4.70 \mathrm{E}-02$ \\
\hline $\operatorname{miR}-150-3 p$ & 184 & Wnt signaling pathway & 5 & 2.7 & $6.00 \mathrm{E}-02$ \\
\hline \multirow[t]{3}{*}{$\operatorname{miR}-151 a-3 p$} & 51 & Renal cell carcinoma & 3 & 5.9 & $1.50 \mathrm{E}-02$ \\
\hline & & ErbB signaling pathway & 3 & 5.9 & $2.30 \mathrm{E}-02$ \\
\hline & & Insulin signaling pathway & 3 & 5.9 & $5.20 \mathrm{E}-02$ \\
\hline \multirow[t]{2}{*}{ miR-193a-5p } & 196 & Huntington's disease & 5 & 2.6 & $7.80 \mathrm{E}-02$ \\
\hline & & Melanogenesis & 4 & 2 & $6.00 \mathrm{E}-02$ \\
\hline miR-1973 & 12 & - & - & - & - \\
\hline \multirow[t]{2}{*}{$\operatorname{miR}-3125$} & 384 & Neurotrophin signaling pathway & 8 & 2.1 & $8.60 \mathrm{E}-03$ \\
\hline & & Wnt signaling pathway & 7 & 1.8 & $6.50 \mathrm{E}-02$ \\
\hline miR-3141 & 13 & - & - & - & - \\
\hline \multirow[t]{4}{*}{$\operatorname{miR}-3156-5 p$} & 320 & Focal adhesion & 11 & 3.4 & $2.00 \mathrm{E}-04$ \\
\hline & & MAPK signaling pathway & 11 & 3.4 & $1.90 \mathrm{E}-03$ \\
\hline & & Pathways in cancer & 9 & 2.8 & $5.60 \mathrm{E}-02$ \\
\hline & & p53 signaling pathway & 4 & 1.2 & $5.60 \mathrm{E}-02$ \\
\hline $\operatorname{miR}-3656$ & 10 & - & - & - & - \\
\hline miR-3663-3p & 305 & MAPK signaling pathway & 12 & 3.9 & $5.90 \mathrm{E}-03$ \\
\hline $\operatorname{miR}-378 b$ & 162 & Pathways in cancer & 8 & 4.9 & $3.60 \mathrm{E}-02$ \\
\hline miR-409-3p & 316 & Axon guidance & 7 & 2.2 & $2.20 \mathrm{E}-02$ \\
\hline miR-409-5p & 34 & MAPK signaling pathway & 3 & 8.8 & $6.20 \mathrm{E}-02$ \\
\hline $\operatorname{miR}-4271$ & 361 & Jak-STAT signaling pathway & 7 & 1.9 & $7.80 \mathrm{E}-02$ \\
\hline \multirow[t]{3}{*}{ miR-575 } & 241 & MAPK signaling pathway & 8 & 3.3 & $7.70 \mathrm{E}-02$ \\
\hline & & Cell cycle & 5 & 2.1 & $9.60 \mathrm{E}-02$ \\
\hline & & mTOR signaling pathway & 4 & 1.7 & $3.50 \mathrm{E}-02$ \\
\hline \multirow[t]{6}{*}{ miR-940 } & 634 & Pathways in cancer & 23 & 3.6 & $1.50 \mathrm{E}-03$ \\
\hline & & MAPK signaling pathway & 16 & 2.5 & $3.70 \mathrm{E}-02$ \\
\hline & & Wnt signaling pathway & 11 & 1.7 & $3.20 \mathrm{E}-02$ \\
\hline & & Jak-STAT signaling pathway & 10 & 1.6 & $8.10 \mathrm{E}-02$ \\
\hline & & TGF- $\beta$ signaling pathway & 9 & 1.4 & $9.00 \mathrm{E}-03$ \\
\hline & & ErbB signaling pathway & 8 & 1.3 & $2.80 \mathrm{E}-02$ \\
\hline \multirow[t]{8}{*}{ miR-98 } & 495 & MAPK signaling pathway & 19 & 3.8 & $1.70 \mathrm{E}-04$ \\
\hline & & Pathways in cancer & 19 & 3.8 & $2.00 \mathrm{E}-03$ \\
\hline & & Wnt signaling pathway & 10 & 2 & $1.70 \mathrm{E}-02$ \\
\hline & & Jak-STAT signaling pathway & 9 & 1.8 & 4.90E-02 \\
\hline & & p53 signaling pathway & 8 & 1.6 & $1.80 \mathrm{E}-03$ \\
\hline & & Insulin signaling pathway & 8 & 1.6 & $6.30 \mathrm{E}-02$ \\
\hline & & TGF- $\beta$ signaling pathway & 7 & 1.4 & $2.60 \mathrm{E}-02$ \\
\hline & & Apoptosis & 6 & 1.2 & $7.70 \mathrm{E}-02$ \\
\hline
\end{tabular}

miRNAs, microRNAs; NHDFs, normal human dermal fibroblasts; KEGG, Kyoto Encyclopedia of Genes and Genomes. 
Table IV. Functional annotation chart for the top 20 miRNAs that were downregulated in the NHDFs $6 \mathrm{~h}$ following exposure to 0.1 Gy $\gamma$-radiation.

\begin{tabular}{|c|c|c|c|c|c|}
\hline $\begin{array}{l}\text { miRNA } \\
\text { (Homo sapiens) }\end{array}$ & $\begin{array}{l}\text { Putative } \\
\text { target genes }\end{array}$ & KEGG pathway & $\begin{array}{l}\text { Genes involved } \\
\text { in the term }\end{array}$ & $\begin{array}{c}\% \text { of involved } \\
\text { genes/total genes }\end{array}$ & P-value \\
\hline let- $7 b-3 p$ & 610 & $\begin{array}{l}\text { Pathways in cancer } \\
\text { MAPK signaling pathway } \\
\text { Wnt signaling pathway } \\
\text { TGF- } \beta \text { signaling pathway }\end{array}$ & $\begin{array}{r}23 \\
18 \\
12 \\
9\end{array}$ & $\begin{array}{l}3.8 \\
3 \\
2 \\
1.5\end{array}$ & $\begin{array}{l}6.80 \mathrm{E}-04 \\
4.90 \mathrm{E}-03 \\
8.70 \mathrm{E}-03 \\
6.40 \mathrm{E}-03\end{array}$ \\
\hline let- $7 d-3 p$ & - & - & - & - & - \\
\hline let-7e-3p & 2 & - & - & - & - \\
\hline miR-1296 & 91 & - & - & - & - \\
\hline miR-130b-5p & 361 & Ubiquitin-mediated proteolysis & 6 & 1.7 & $6.10 \mathrm{E}-02$ \\
\hline miR-1976 & 429 & $\begin{array}{l}\text { Drug metabolism } \\
\text { Pyrimidine metabolism }\end{array}$ & $\begin{array}{l}5 \\
5\end{array}$ & $\begin{array}{l}1.2 \\
1.2\end{array}$ & $\begin{array}{l}5.90 \mathrm{E}-03 \\
7.90 \mathrm{E}-02\end{array}$ \\
\hline miR-204-5p & 178 & $\begin{array}{l}\text { Jak-STAT signaling pathway } \\
\text { Huntington's disease } \\
\text { Melanogenesis }\end{array}$ & $\begin{array}{l}5 \\
5 \\
4\end{array}$ & $\begin{array}{l}2.8 \\
2.8 \\
2.2\end{array}$ & $\begin{array}{l}5.00 \mathrm{E}-02 \\
7.80 \mathrm{E}-02 \\
6.00 \mathrm{E}-02\end{array}$ \\
\hline $\operatorname{miR}-211-5 p$ & 178 & $\begin{array}{l}\text { Jak-STAT signaling pathway } \\
\text { Melanogenesis }\end{array}$ & $\begin{array}{l}5 \\
4\end{array}$ & $\begin{array}{l}2.8 \\
2.2\end{array}$ & $\begin{array}{l}5.40 \mathrm{E}-02 \\
6.30 \mathrm{E}-02\end{array}$ \\
\hline miR-328 & 103 & $\begin{array}{l}\text { p53 signaling pathway } \\
\text { mTOR signaling pathway }\end{array}$ & $\begin{array}{l}4 \\
3\end{array}$ & $\begin{array}{l}3.9 \\
2.9\end{array}$ & $\begin{array}{l}4.30 \mathrm{E}-03 \\
2.60 \mathrm{E}-02\end{array}$ \\
\hline $\operatorname{miR}-335-3 p$ & 2,294 & $\begin{array}{l}\text { Pathways in cancer } \\
\text { MAPK signaling pathway } \\
\text { Calcium signaling pathway } \\
\text { Wnt signaling pathway } \\
\text { Insulin signaling pathway } \\
\text { TGF- } \beta \text { signaling pathway } \\
\text { ErbB signaling pathway } \\
\text { p53 signaling pathway }\end{array}$ & $\begin{array}{l}56 \\
39 \\
33 \\
28 \\
22 \\
21 \\
21 \\
14\end{array}$ & $\begin{array}{l}2.4 \\
1.7 \\
1.4 \\
1.2 \\
1 \\
0.9 \\
0.9 \\
0.6\end{array}$ & $\begin{array}{l}1.20 \mathrm{E}-03 \\
7.20 \mathrm{E}-02 \\
3.70 \mathrm{E}-03 \\
9.20 \mathrm{E}-03 \\
7.60 \mathrm{E}-02 \\
1.20 \mathrm{E}-03 \\
1.20 \mathrm{E}-03 \\
3.70 \mathrm{E}-02\end{array}$ \\
\hline $\operatorname{miR}-449-3 p$ & 305 & $\begin{array}{l}\text { Pathways in cancer } \\
\text { Neurotrophin signaling pathway }\end{array}$ & $\begin{array}{r}10 \\
7\end{array}$ & $\begin{array}{l}3.3 \\
2.3\end{array}$ & $\begin{array}{l}9.50 \mathrm{E}-02 \\
1.70 \mathrm{E}-02\end{array}$ \\
\hline $\operatorname{miR}-454-5 p$ & 33 & - & - & - & - \\
\hline $\operatorname{miR}-483-3 p$ & 155 & $\begin{array}{l}\text { RNA degradation } \\
\text { Purine metabolism }\end{array}$ & $\begin{array}{l}5 \\
4\end{array}$ & $\begin{array}{l}3.2 \\
2.6\end{array}$ & $\begin{array}{l}7.10 \mathrm{E}-04 \\
9.90 \mathrm{E}-02\end{array}$ \\
\hline $\operatorname{miR}-519 d$ & 739 & $\begin{array}{l}\text { MAPK signaling pathway } \\
\text { Insulin signaling pathway } \\
\text { Chemokine signaling pathway } \\
\text { TGF- } \beta \text { signaling pathway } \\
\text { ErbB signaling pathway }\end{array}$ & $\begin{array}{r}23 \\
12 \\
12 \\
10 \\
9\end{array}$ & $\begin{array}{l}3.1 \\
1.6 \\
1.6 \\
1.4 \\
1.2\end{array}$ & $\begin{array}{l}3.20 \mathrm{E}-04 \\
1.10 \mathrm{E}-02 \\
8.80 \mathrm{E}-02 \\
4.70 \mathrm{E}-03 \\
1.50 \mathrm{E}-02\end{array}$ \\
\hline $\operatorname{miR}-520 d-3 p$ & 647 & $\begin{array}{l}\text { MAPK signaling pathway } \\
\text { Regulation of actin cytoskeleton } \\
\text { Pathways in cancer } \\
\text { Insulin signaling pathway } \\
\text { TGF- } \beta \text { signaling pathway } \\
\text { ErbB signaling pathway }\end{array}$ & $\begin{array}{r}19 \\
15 \\
15 \\
11 \\
8 \\
8\end{array}$ & $\begin{array}{l}2.9 \\
2.3 \\
2.3 \\
1.7 \\
1.2 \\
1.2\end{array}$ & $\begin{array}{l}3.30 \mathrm{E}-04 \\
2.20 \mathrm{E}-03 \\
6.60 \mathrm{E}-02 \\
3.80 \mathrm{E}-03 \\
9.60 \mathrm{E}-03 \\
9.60 \mathrm{E}-03\end{array}$ \\
\hline miR-521 & 6 & - & - & - & - \\
\hline miR-595 & 35 & - & - & - & - \\
\hline miR-615-3p & 25 & - & - & - & - \\
\hline miR-885-5p & 280 & $\begin{array}{l}\text { Tight junction } \\
\text { RNA degradation }\end{array}$ & $\begin{array}{l}7 \\
5\end{array}$ & $\begin{array}{l}2.5 \\
1.8\end{array}$ & $\begin{array}{l}8.00 \mathrm{E}-03 \\
6.40 \mathrm{E}-03\end{array}$ \\
\hline miR-937 & 5 & - & - & - & - \\
\hline
\end{tabular}

miRNAs, microRNAs; NHDFs, normal human dermal fibroblasts; KEGG, Kyoto Encyclopedia of Genes and Genomes. 
Table V. Functional annotation chart for the top 20 upregulated and the single downregulated miRNA in NHDFs $24 \mathrm{~h}$ following exposure to 0.1 Gy $\gamma$-radiation.

\begin{tabular}{|c|c|c|c|c|c|}
\hline $\begin{array}{l}\text { miRNA } \\
\text { (Homo sapiens) }\end{array}$ & $\begin{array}{c}\text { Putative } \\
\text { target genes }\end{array}$ & KEGG pathway & $\begin{array}{l}\text { Genes involved } \\
\text { in the term }\end{array}$ & $\begin{array}{c}\% \text { of involved } \\
\text { genes/total genes }\end{array}$ & P-value \\
\hline $\operatorname{miR}-1224-5 p$ & 263 & Axon guidance & 5 & 1.9 & $5.00 \mathrm{E}-02$ \\
\hline $\operatorname{miR}-129-2-3 p$ & 181 & Valine, leucine and isoleucine degradation & 3 & 1.7 & $5.30 \mathrm{E}-02$ \\
\hline $\operatorname{miR}-17-3 p$ & 384 & $\begin{array}{l}\text { MAPK signaling pathway } \\
\text { Insulin signaling pathway } \\
\text { mTOR signaling pathway } \\
\text { TGF- } \beta \text { signaling pathway }\end{array}$ & $\begin{array}{r}12 \\
7 \\
6 \\
5\end{array}$ & $\begin{array}{l}3.1 \\
1.8 \\
1.6 \\
1.3\end{array}$ & $\begin{array}{l}7.60 \mathrm{E}-03 \\
3.30 \mathrm{E}-02 \\
2.20 \mathrm{E}-03 \\
7.00 \mathrm{E}-02\end{array}$ \\
\hline $\operatorname{miR}-1825$ & 390 & $\begin{array}{l}\text { Pathways in cancer } \\
\text { MAPK signaling pathway }\end{array}$ & $\begin{array}{l}13 \\
10\end{array}$ & $\begin{array}{l}3.3 \\
2.6\end{array}$ & $\begin{array}{l}1.30 \mathrm{E}-02 \\
4.80 \mathrm{E}-02\end{array}$ \\
\hline $\operatorname{miR}-197-3 p$ & 422 & Ubiquitin mediated proteolysis & 8 & 1.9 & $2.60 \mathrm{E}-02$ \\
\hline $\operatorname{miR}-299-3 p$ & 238 & Purine metabolism & 5 & 2.1 & $6.20 \mathrm{E}-02$ \\
\hline $\operatorname{miR}-3180-5 p$ & 629 & $\begin{array}{l}\text { Axon guidance } \\
\text { Wnt signaling pathway }\end{array}$ & $\begin{array}{l}11 \\
10\end{array}$ & $\begin{array}{l}1.7 \\
1.6\end{array}$ & $\begin{array}{l}6.20 \mathrm{E}-03 \\
4.30 \mathrm{E}-02\end{array}$ \\
\hline $\operatorname{miR}-33 b-3 p$ & 147 & - & - & - & - \\
\hline $\operatorname{miR}-3646$ & 656 & $\begin{array}{l}\text { Ubiquitin mediated proteolysis } \\
\text { Wnt signaling pathway } \\
\text { Phosphatidylinositol signaling system }\end{array}$ & $\begin{array}{r}14 \\
12 \\
6\end{array}$ & $\begin{array}{l}2.1 \\
1.8 \\
0.9\end{array}$ & $\begin{array}{l}4.70 \mathrm{E}-04 \\
9.90 \mathrm{E}-03 \\
9.30 \mathrm{E}-02\end{array}$ \\
\hline $\operatorname{miR}-3648$ & 3 & - & - & - & - \\
\hline miR-369-3p & 1,171 & $\begin{array}{l}\text { Pathways in cancer } \\
\text { MAPK signaling pathway } \\
\text { Jak-STAT signaling pathway } \\
\text { TGF- } \beta \text { signaling pathway } \\
\text { ErbB signaling pathway } \\
\text { p53 signaling pathway }\end{array}$ & $\begin{array}{r}34 \\
23 \\
16 \\
15 \\
12 \\
9\end{array}$ & $\begin{array}{l}2.9 \\
2 \\
1.4 \\
1.3 \\
1 \\
0.8\end{array}$ & $\begin{array}{l}1.10 \mathrm{E}-03 \\
5.80 \mathrm{E}-02 \\
3.40 \mathrm{E}-02 \\
4.10 \mathrm{E}-04 \\
1.10 \mathrm{E}-02 \\
4.20 \mathrm{E}-02\end{array}$ \\
\hline $\operatorname{miR}-369-5 p$ & 2 & - & - & - & - \\
\hline $\operatorname{miR}-3937$ & 11 & - & - & - & - \\
\hline $\operatorname{miR}-431-5 p$ & 307 & Aldosterone-regulated sodium reabsorption & 4 & 1.3 & $2.00 \mathrm{E}-02$ \\
\hline $\operatorname{miR}-454-3 p$ & 546 & $\begin{array}{l}\text { Endocytosis } \\
\text { Insulin signaling pathway } \\
\text { Phosphatidylinositol signaling system } \\
\text { TGF- } \beta \text { signaling pathway } \\
\text { mTOR signaling pathway } \\
\text { Inositol phosphate metabolism }\end{array}$ & $\begin{array}{r}16 \\
9 \\
8 \\
7 \\
5 \\
5\end{array}$ & $\begin{array}{l}2.9 \\
1.6 \\
1.5 \\
1.3 \\
0.9 \\
0.9\end{array}$ & $\begin{array}{l}2.80 \mathrm{E}-04 \\
4.40 \mathrm{E}-02 \\
5.60 \mathrm{E}-03 \\
4.10 \mathrm{E}-02 \\
6.50 \mathrm{E}-02 \\
7.20 \mathrm{E}-02\end{array}$ \\
\hline $\operatorname{miR}-513 c-5 p$ & 160 & $\begin{array}{l}\text { Tight junction } \\
\text { Phosphatidylinositol signaling system }\end{array}$ & $\begin{array}{l}4 \\
3\end{array}$ & $\begin{array}{l}2.5 \\
1.9\end{array}$ & $\begin{array}{l}4.00 \mathrm{E}-02 \\
6.60 \mathrm{E}-02\end{array}$ \\
\hline miR-602 & 22 & - & - & - & - \\
\hline $\operatorname{miR}-625-5 p$ & 357 & $\begin{array}{l}\text { Tight junction } \\
\text { Ubiquitin mediated proteolysis } \\
\text { Apoptosis }\end{array}$ & $\begin{array}{l}8 \\
8 \\
7\end{array}$ & $\begin{array}{l}2.2 \\
2.2 \\
2\end{array}$ & $\begin{array}{l}9.20 \mathrm{E}-03 \\
1.00 \mathrm{E}-02 \\
4.20 \mathrm{E}-03\end{array}$ \\
\hline $\operatorname{miR}-629-3 p$ & 563 & $\begin{array}{l}\text { PPAR signaling pathway } \\
\text { Riboflavin metabolism }\end{array}$ & $\begin{array}{l}6 \\
3\end{array}$ & $\begin{array}{l}1.1 \\
0.5\end{array}$ & $\begin{array}{l}3.20 \mathrm{E}-02 \\
6.20 \mathrm{E}-02\end{array}$ \\
\hline $\operatorname{miR}-765$ & 696 & $\begin{array}{l}\text { Endocytosis } \\
\text { MAPK signaling pathway } \\
\text { Wnt signaling pathway } \\
\text { TGF- } \beta \text { signaling pathway }\end{array}$ & $\begin{array}{r}11 \\
18 \\
12 \\
9\end{array}$ & $\begin{array}{l}1.6 \\
3 \\
2 \\
1.5\end{array}$ & $\begin{array}{l}9.50 \mathrm{E}-02 \\
4.90 \mathrm{E}-03 \\
8.70 \mathrm{E}-03 \\
6.40 \mathrm{E}-03\end{array}$ \\
\hline miR-634a & 240 & Ubiquitin-mediated proteolysis & 6 & 2.5 & $5.60 \mathrm{E}-02$ \\
\hline
\end{tabular}

miR-634 is only the downregulated miRNAs. miRNAs, microRNAs; NHDFs, normal human dermal fibroblasts. 
In conclusion, to the best of our knowledge, we provide the first evidence that LDR $(0.1 \mathrm{~Gy})$ induces dual radio-adaptive responses in NHDFs. We also demonstrated that LDR induced potential anti-aging effects through the regulation of the expression of collagen synthesis-relating genes. Furthermore, LDR induced changes in the expression profiles of specific miRNAs, and some of the deregulated miRNAs were specific to the early or late radio-adaptive response. Although further studies are required to validate the deregulated miRNAs, our results provide novel information on miRNA-mediated adaptive responses to LDR in NHDFs.

\section{Acknowledgements}

Dr Seunghee Bae was supported by the KU Research Professor Program of Konkuk University, and this study was supported by grant no. 20131610101840 from the Ministry of Trade, Industry and Energy of Republic of Korea.

\section{References}

1. Nguyen PK and Wu JC: Radiation exposure from imaging tests: is there an increased cancer risk? Expert Rev Cardiovasc Ther 9: 177-183, 2011.

2. Cleaver JE: Biology and genetics in the biological effects of ionizing radiation (BEIR VII) report. Health Physics 89: S32-S32, 2005.

3. Feinendegen LE: Evidence for beneficial low level radiation effects and radiation hormesis. Br J Radiol 78: 3-7, 2005.

4. Sjerobabski-Masnec I and Situm M: Skin aging. Acta Clin Croat 49: 515-518, 2010.

5. Gelse K, Pöschl E and Aigner T: Collagens - structure, function, and biosynthesis. Adv Drug Deliv Rev 55: 1531-1546, 2003.

6. Quan T, Qin Z, Xia W, Shao Y, Voorhees JJ and Fisher GJ: Matrix-degrading metalloproteinases in photoaging. J Investig Dermatol Symp Proc 14: 20-24, 2009.

7. Constable PH, Crowston JG, Occleston NL and Khaw PT: The effects of single doses of beta radiation on the wound healing behaviour of human Tenon's capsule fibroblasts. Br J Ophthalmol 88: 169-173, 2004.

8. Rastogi RP, Richa, Kumar A, Tyagi MB and Sinha RP: Molecular mechanisms of ultraviolet radiation-induced DNA damage and repair. J Nucleic Acids 2010: 592980, 2010
9. Chang TC, Wentzel EA, Kent OA, et al: Transactivation of miR-34a by 53 broadly influences gene expression and promotes apoptosis. Mol Cell 26: 745-752, 2007.

10. He L, He X, Lim LP, et al: A microRNA component of the p53 tumour suppressor network. Nature 447: 1130-1134, 2007.

11. Liu C, Zhou C, Gao F, et al: MiR-34a in age and tissue related radio-sensitivity and serum miR-34a as a novel indicator of radiation injury. Int J Biol Sci 7: 221-233, 2011.

12. Joly-Tonetti $\mathbf{N}$, Viñuelas $\mathbf{J}$, Gandrillon $\mathrm{O}$ and Lamartine $\mathrm{J}$ : Differential miRNA expression profiles in proliferating or differentiated keratinocytes in response to gamma irradiation. BMC Genomics 14: 184, 2013.

13. Cha HJ, Seong KM, Bae S, et al: Identification of specific microRNAs responding to low and high dose $\gamma$-irradiation in the human lymphoblast line IM9. Oncol Rep 22: 863-868, 2009.

14. Cha HJ, Shin S, Yoo H, et al: Identification of ionizing radiationresponsive microRNAs in the IM9 human B lymphoblastic cell line. Int J Oncol 34: 1661-1668, 2009.

15. Cha HJ, Lee KS, Lee GT, et al: Altered miRNA expression profiles are involved in the protective effects of troxerutin against ultraviolet B radiation in normal human dermal fibroblasts. Int J Mol Med 33: 957-963, 2014

16. Paraskevopoulou MD, Georgakilas G, Kostoulas N, et al: DIANA-microT web server v5.0: service integration into miRNA functional analysis workflows. Nucleic Acids Res 41: W169-W173, 2013.

17. Huang da W, Sherman BT and Lempicki RA: Systematic and integrative analysis of large gene lists using DAVID bioinformatics resources. Nat Protoc 4: 44-57, 2009.

18. Kraemer A, Anastasov N, Angermeier M, Winkler K, Atkinson MJ and Moertl S: MicroRNA-mediated processes are essential for the cellular radiation response. Radiat Res 176: 575-586, 2011.

19. Huang Y, Shen XJ, Zhou Q, Wang SP, Tang SM and Zhang GZ: Biological functions of microRNAs: a review. J Physiol Biochem 67: 129-139, 2011.

20. Fernet M, Mégnin-Chanet F, Hall J and Favaudon V: Control of the $\mathrm{G} 2 / \mathrm{M}$ checkpoints after exposure to low doses of ionising radiation: implications for hyper-radiosensitivity. DNA Repair (Amst) 9: 48-57, 2010

21. Varga J and Abraham D: Systemic sclerosis: a prototypic multisystem fibrotic disorder. J Clin Invest 117: 557-567, 2007.

22. Wei LC, Ding YX, Liu YH, et al: Low-dose radiation stimulates Wnt $/ \beta$-catenin signaling, neural stem cell proliferation and neurogenesis of the mouse hippocampus in vitro and in vivo. Curr Alzheimer Res 9: 278-289, 2012. 